\title{
A ideologia em Althusser e Laclau: diálogos (im)pertinentes
}

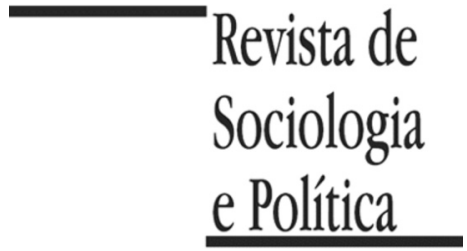

DOI: $10.1590 / 0104-447814225009$

\author{
Luiz Eduardo Motta e Carlos Henrique Aguiar Serra
}

\begin{abstract}
RESUMO
A teoria política de Ernesto Laclau é uma das principais referências no campo da Ciência Política ao debate sobre o populismo e a democracia contemporânea, além de sua contribuição ao conceito de ideologia e na análise de discurso. Contudo, os estudos sobre este autor não têm explorado a influência do marxismo, sobretudo de Louis Althusser, em sua obra. O objetivo deste trabalho é resgatar essa influência e apontar o diálogo entre esses dois autores, tendo como elo os conceitos (que possuem certa ligação com a psicanálise de Lacan) de ideologia e sobredeterminação, além da questão da contingência que se tornou um dos aspectos mais relevantes na obra de ambos os autores a partir da década de 1980. Para compreendermos a contribuição de Althusser e Laclau ao conceito de ideologia, analisamos dois eixos: (i) o primeiro trata da inovação que Althusser dá a esse conceito ao situá-lo no plano das relações imaginárias e na definição de sujeito descentrado; (ii) em seguida, a contribuição de Laclau a partir dos pressupostos althusserianos, dando uma nova definição à ideologia populista-nacionalista, e a redefinição de sua teoria ao privilegiar o conceito de discurso em substituição ao de ideologia. Na conclusão apontamos que o conceito de ideologia de Althusser demonstra ter mais precisão conceitual por ser definido como uma prática articulada a outras práticas distintamente da concepção discursiva (e reducionista) defendida posteriormente por Laclau. Percebemos, portanto, que a teoria da ideologia de Althusser mantém-se atual no campo do pensamento crítico, não somente no que concerne aos aspectos reprodutores, mas também transformadores das relações de poder.
\end{abstract}

PALAVRAS-CHAVE: ideologia; sobredeterminação; discurso; Althusser; Laclau.

Recebido em 21 de Agosto de 12. Aprovado em 05 de Maio de 13.

\section{Introdução ${ }^{1}$}

\footnotetext{
${ }^{1}$ Trabalho apresentado no $8^{\circ}$ Encontro da Associação Brasileira de Ciência Política (ABCP), de 2012. Agradecemos aos pareceristas anônimos da Revista de Sociologia e Política pelos comentários tecidos ao nosso texto.
}

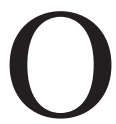
conceito de ideologia no século XIX e no século XX desfrutou de um grande alcance no campo das Ciências Sociais, particularmente na Ciência Política e na Sociologia. Tendo como ponto de partida a obra de Destutt de Tracy, Eléments d'idéologie (1817-1818), esse conceito teve em Marx, e no pensamento marxista, um lugar central para o entendimento tanto da reprodução como das mudanças na sociedade e na política. O conceito de ideologia encontrou também fora do marxismo reflexões e análises sobre o seu significado sociopolítico, a exemplo dos trabalhos de Emile Durkheim, Karl Mannheim, Robert King Merton e Jürgen Habermas. Contudo, desde a guerra fria, o conceito de ideologia começou a ser questionado, sendo considerado "ultrapassado", em uma leitura em que o reduzia apenas a seu aspecto político e utópico, considerando que o seu "fim" já teria chegado. Exemplo disso são os trabalhos de Raymond Aron, $O$ ópio dos intelectuais (1955), e o de Daniel Bell, O fim da ideologia (1960).

O questionamento do conceito de ideologia agravou-se em meados dos anos 1980, e, sobretudo, a partir da queda do Muro de Berlim, com a emergência do pós-modernismo e do pós-estruturalismo. Além disso, o artigo polêmico de Francis Fukuyama, "O fim da história", no qual afirmava que a história teria chegado a seu fim com a vitória do liberalismo sobre o socialismo, do predomínio do indivíduo sobre o coletivo, e do mercado sobre o planejamento. Não 
${ }^{2}$ Veja Rancière (2011) [1974], Poulantzas (1978b) [1971], Pêcheux (2009) [1975], Badiou e Balmès (1976), Hall (1983) [1977], Therborn (1980). No Brasil destacam-se os trabalhos pioneiros de Escobar $(1975 ; 1978)$, a crítica de Cardoso (1977) e a resposta à crítica de Cardoso por Pires (1978), e o artigo "'introdutório" de Albuquerque (1983) ao livro Aparelhos ideológicos de Estado. Em um amplo mapeamento do tema, ver Konder (2002). As datas em colchete representam o ano da edição original dos livros citados. haveria, assim, mais alternativa para além do liberalismo. E é nesse contexto em que começou a prevalecer, no campo das Ciências Sociais, os conceitos de simbólico e de discurso em detrimento ao de ideologia.

Mas com o início do esgotamento do modelo neoliberal na segunda metade dos anos 1990, o conceito de ideologia, tal como a fênix, ressurgiu das cinzas e retornou a despertar novas reflexões, além da recuperação de obras clássicas sobre esse conceito. Um dos principais responsáveis por esse revival foi sem dúvida Slavoj Zizek, ao articular o conceito de ideologia marxista com a psicanálise lacaniana e a filosofia hegeliana. E o livro que ele organizou, Um mapa da ideologia, foi um marco para essa recuperação, não só do conceito de ideologia, mas também da contribuição de Louis Althusser para essa problemática. Embora a obra desse filósofo tenha sido eclipsada nos anos 1980 quando o marxismo europeu e, sobretudo, o francês, entrou em crise, o seu resgate iniciou-se aos poucos nos anos 1990 com a publicação de sua autobiografia $O$ futuro dura muito tempo, conjuntamenteaos seus textos inéditos, e com a recuperação dos seus trabalhos publicados nos anos 1960 e 1970. Dos seus textos inéditos, um dos mais importantes foi escrito em 1969 sobre o tema em tela: trata-se do livro Sobre a reprodução, que vem a ser versão ampliada do artigo "Ideologia e aparelhos ideológicos de Estado", publicado em 1970. Esse artigo, como é de notório conhecimento, teve um grande impacto e repercussão desde a sua primeira publicação, além de ter exercido uma influência para diversos autores, a exemplo da obra de Ernesto Laclau. Laclau, sem dúvida, é uma das principais expressões intelectuais vivas do campo da Ciência Política e da Sociologia. Sua obra vem repercutindo em diversas formações sociais e tem sido objeto de discussão por diversos intelectuais, sobretudo do campo de esquerda, a exemplo de Zizek, Badiou e Boron. Seu livro de 1977, Política e ideologia na teoria marxista, obteve uma forte repercussão (sobretudo na sua análise sobre o conceito de ideologia, principalmente na sua forma nacionalpopular, ou populista), e somou-se a outros importantes trabalhos influenciados, ou motivados, por Althusser na problemática da ideologia naquele contexto $^{2}$.

No entanto, apesar de Laclau ter dado uma significativa contribuição ao conceito de ideologia, foi também um dos principais "coveiros" desse conceito ao publicar, em parceria com Chantal Mouffe em 1985, o livro Hegemonia e estratégia socialista. Ao afirmar que o conceito de ideologia não respondia mais à realidade contemporânea, Laclau optou em priorizar o conceito de discurso que, a partir de então, será central na sua teoria sociopolítica, definida por ele como "pós-marxista".

Esse artigo tem como objetivo resgatar a importância e o significado que o conceito de ideologia ainda tem nas Ciências Sociais, particularmente a contribuição de Louis Althusser na "ciência da história" (ou "materialismo histórico"), e a influência de sua teoria na obra de Ernesto Laclau. Ao tratarmos dessa influência, não nos limitaremos à fase inicial de Laclau expressa em Política e ideologia, mas também na sua obra de ruptura com a teoria marxista, Hegemonia e estratégia socialista, pois, como veremos, não deixou de ser influenciada por Althusser, a exemplo do conceito de sobredeterminação e, principalmente, pelo uso do conceito de contingência, pois, como veio à lume nos anos 1990, foi um conceito central na teoria de Althusser quando este, em seus últimos textos, enfatizou o materialismo do encontro (ou do acaso), mudando em vários aspectos da sua teoria dos anos 1960 e 1970. 
Este trabalho divide-se em três partes centrais: na primeira trataremos da inovadora definição que Althusser deu a esse conceito desde os seus primeiros trabalhos em Pour Marx e Ler o Capital e, principalmente, em sua derradeira análise contida no livro Sobre a reprodução, onde encontra-se as principais linhas expostas no artigo Ideologia e aparelhos ideológicos de Estado. Em seguida, mostraremos a contribuição de Laclau ao conceito de ideologia - privilegiando a sua análise sobre os princípios articulátorios da ideologia populista-nacionalista - e a reviravolta em sua teoria a partir do livro Hegemonia e estratégia socialista. Por fim, na conclusão, onde apontamos que o conceito de ideologia de Althusser demonstra ter mais precisão conceitual por ser definido como uma prática articulada a outras práticas distintamente da concepção discursiva (e reducionista) defendida posteriormente por Laclau.

\section{A ideologia como imaginário das relações com o mundo real: Louis Althusser}

\footnotetext{
${ }^{3}$ Vide os trabalhos de Ípola (2007), Gillot (2010), Sampedro (2010) e as coletâneas organizadas por Caletti e Romé (2011) e Caletti, Romé e Sosa (2011).
}

A intervenção de Althusser na teoria marxista sobre o conceito de ideologia gerou um intenso debate que continua até os dias de hoje ${ }^{3}$. Como bem observa Sampedro (2010), Althusser trabalhou o conceito de ideologia: (i) do ponto de vista epistemológico, no qual trata a relação entre ciência e ideologia, e em grande parte presente nos seus primeiros trabalhos, notadamente Pour Marx e Ler o capital; (ii) no sentido prático, onde tem inicio no artigo "Marxismo e humanismo" e é amplamente desenvolvido no manuscrito Sobre a reprodução, de onde foi extraído o seu mais famoso artigo, "Ideologia e aparelhos ideológicos de Estado".

No aspecto epistemológico, a ideologia é definida como o outro da ciência, i.e, a ciência surge como uma ruptura, uma descontinuidade do senso comum, da ideologia. Para Althusser, há uma ruptura epistemológica na obra de Marx a partir de 1845 , quando se inicia um novo continente científico, a ciência da história (ou materialismo histórico) e, em estado prático, uma nova filosofia produtora de conhecimento (materialismo dialético).

Tendo como suporte o texto de Marx Introdução crítica da economia política, distingue-se o real do pensamento, implicando duas teses fundamentais: (i) a tese materialista do primado do real sobre o pensamento, dado que o pensamento do real pressupõe a existência do real independentemente do seu pensamento, pois para Marx o sujeito real, como antes, continua a existir em sua autonomia fora da cabeça (Marx 2011, p. 55); (ii) A tese materialista da especificidade do pensamento e do processo de pensamento em relação ao real e ao processo real. O pensamento do real, a concepção do real, e todas as operações de pensamento pelas quais o real é pensado e concebido, pertencem à ordem do pensar, ao elemento do pensamento e do processo que não se pode se confundir, com o elemento do real. "O todo como um todo de pensamentos, tal como aparece na cabeça, é um produto da cabeça pensante" (ibidem). Do mesmo modo, o concreto pensado pertence ao pensar e não ao real. O processo do conhecimento, o trabalho de elaboração pelo qual o pensamento transforma as intuições e as representações do início em conhecimentos, ou concreto de pensamento, dá-se inteiramente no pensamento.

A partir dessa definição de Marx da separação do real em relação ao abstrato, ou do concreto-do-pensamento e do concreto-realidade, como diz Althusser, o filósofo marxista franco-argelino começa a elaborar o seu conceito de práticas no artigo "Sobre a dialética materialista" em Pour Marx. Por prática, em geral, entende-se todo processo de transformação de uma determinada 
matéria-prima dada em um produto determinado, transformação efetuada por um determinado trabalho humano, utilizando meios ("de produção") determinados (Althusser 1986, p. 167). Há, portanto, distintas práticas articuladas entre si (econômica, política, ideológica e teórica), havendo o predomínio de uma sobre a outra, de acordo com a contradição dominante em uma conjuntura dada.

Segundo Althusser, a prática teórica não comporta somente a prática teórica científica, mas também a prática teórica pré-científica, i.e, ideológica. Para ele, a prática teórica de uma ciência diferencia-se sempre claramente da prática teórica ideológica da sua pré-história: essa distinção toma a forma de uma descontinuidade "qualitativa" teórica e histórica que ele designa, inspirado em Bachelard de "corte epistemológico" (idem). Isso significa, para Althusser, que as correntes filosóficas do empirismo, da fenomenologia e do idealismo, seriam ideologias. O mesmo pode-se dizer sobre o funcionalismo, a etnometodologia e o neo-institucionalismo no campo das Ciências Sociais. A prática teórica seria estabelecida em três momentos: o primeiro seria o da Generalidade I constituída da matéria-prima ideológica que será transformada em um conceito científico (Generalidade III) por meio dos conceitos já constituídos, que é a Generalidade II (idem, pp. 187-189).

A relação entre a ideologia e a ciência, embora conflituosa, é interdependente, já que a ciência emerge a partir das pré-noções científicas, i.e, ideológicas. Como observa Sampedro "se toda ciência nasce e se desenvolve excluindo a ideologia, também é certo que as noções próprias da ideologia se descrevem como indicadores da ciência, no sentido de que a ciência produz o conhecimento de um objeto cuja existência está indicada na região da ideologia. Isso implica que a ideologia seja sempre ideologia para uma ciência" (Sampedro 2010, p. 33).

Se a ciência é aberta, mas politicamente não flexível (embora possa ser instrumentalizada), a ideologia para Althusser tem outra característica. Em Ler o capital, ele afirma que "se a ideologia não exprime a essência objetiva total do seu tempo (a essência do presente histórico), pode, pelo menos, exprimir muito bem, pelo efeito de leves deslocamentos internos de ênfase, as transformações atuais da situação histórica: diferentemente de uma ciência, uma ideologia é ao mesmo tempo teoricamente fechada e politicamente maleável e adaptável. Ela se curva às necessidades da época, mas sem movimento aparente, contentando-se com o refletir por alguma modificação imperceptível de suas próprias relações internas, as transformações históricas que ela tem por missão assimilar e dominar. [...] A ideologia muda, pois, mas imperceptivelmente, conservando, a forma de ideologia; ela se move, mas com um movimento imóvel, que a mantém no mesmo lugar, em seu lugar e função de ideologia" (Althusser 1980, p. 87; grifos no original).

O sentido prático da ideologia tem o seu primeiro esboço em Pour Marx, quando Althusser define que a ideologia é uma instância, uma região, do todocomplexo-estruturado, i.e, um nível do modo de produção, conjuntamente com o econômico e o jurídico-político. Mas é em Marxismo e humanismo onde Althusser constrói o significado da ideologia como uma estrutura imanente do imaginário na sociedade. Não há, por parte de Althusser, uma definição negativa da ideologia como uma falsidade do real, uma "falsa consciência". A ideologia faz organicamente parte de toda uma totalidade social. Tudo se passa como se as sociedades humanas não pudessem subsistir sem essas estruturas específicas, esses sistemas de representações que são as ideologias. Como ele 
afirma "as sociedades humanas segregam a ideologia como o elemento e a atmosfera mesma indispensável à sua respiração, à sua vida histórica. Só uma concepção ideológica do mundo pôde imaginar sociedades sem ideologias, e admitir a idéia utópica de um mundo onde a ideologia (e não de uma de suas formas históricas) desapareceria sem deixar rastro, para ser substituída pela ciência" (Althusser 1986, p. 239). Isso significa, primeiramente, afirmar o que mudam são as ideologias históricas, mas a estrutura ideológica permanece em qualquer forma de sociedade, inclusive na comunista. E, em segundo, a ciência não é um substitutivo da ideologia, já que a relação entre a ciência e a ideologia dá-se no plano do conhecimento, na prática teórica.

A ideologia não é, portanto, uma aberração ou uma excrescência contingente da História: é uma estrutura essencial à vida histórica das sociedades. Tampouco pertence à região da consciência. Ela é profundamente inconsciente. A ideologia, para Althusser, é um sistema de representações, mas essas representações na maior parte das vezes imagens, às vezes conceitos, mas é antes de tudo como estruturas que elas se impõem aos homens sem passar para a sua "consciência". A ideologia refere-se, então, à relação "vivida" dos homens no seu mundo. Essa relação não parece consciente" a não ser na condição de ser inconsciente, parece, da mesma maneira, não ser simples a não ser na condição de ser complexa, de não ser uma relação simples, mas uma relação de relações, uma relação de segundo grau. Na ideologia "os homens expressam, com efeito, não as suas relações nas suas condições de existência: o que supõe, ao mesmo tempo, relação real e relação 'vivida', 'imaginária' A ideologia é, então, a expressão da relação dos homens com o seu 'mundo', isto é, a unidade (sobredeterminada) da sua relação real e da sua relação imaginária com as suas condições de existência reais. [...] É nessa sobredeterminação do real pelo imaginário e do imaginário pelo real que a ideologia é, em seu princípio, ativa, que ela reforça ou modifica a relação dos homens com as suas condições de existência, na sua própria relação imaginária" (idem,pp. 240-241).

Se a ideologia é uma estrutura de um todo-complexo marcado por contradições e antagonismos, há desigualdades entre as ideologias particulares, já que há o confronto da ideologia da classe dominante com a da classe dominada. A classe dominante não mantém uma relação de exterioridade com a ideologia, muito menos a instrumentaliza. De acordo com Althusser, a burguesia vive a sua ideologia, já que ela crê no seu mito (a liberdade, o homem, a razão, a igualdade perante a lei etc.), e o que ela vive na sua ideologia é essa relação imaginária com as suas condições de existência reais, que lhe permite às vezes agir sobre si e sobre os outros a fim de assumir, de preencher e de suportar o seu papel histórico de classe dominante. Se toda a função social da ideologia resumisse-se ao cinismo de um mito e à instrumentalização da ideologia, que a classe dominante fabricaria e manipularia de fora para enganar aqueles que ela explora, a ideologia desapareceria com as classes. Em suma, e parafraseando Aristóteles quando este afirmou em A política que o homem é um "animal político", para Althusser o homem é um "animal ideológico" (Althusser s/d, p. 196).

Entre o artigo "Marxismo e humanismo" e "Ideologia e aparelhos ideológicos de Estado", foi publicado, em 1966, o texto Prática teórica e luta ideológica,no qual, além de retomar a sua tese da ideologia como imaginário e começar a desenvolver o efeito do reconhecimento-desconhecimento da ideologia, e também de diferenciar a prática ideológica da prática teórica, Althusser aborda em diversas passagens o significado da ideologia como uma instância do modo de produção a exemplo dessa citação "para compreender 
${ }^{4}$ Como observa Gillot ""A concepção freudiana do inconsciente desempenha, com efeito, o papel de referência fundamental para a elaboração althusseriana do conceito de ideologia" (Gillot 2010, p. 79).

\footnotetext{
5 "Basta compreender o estado do espelho como uma identificação, no sentido pleno que a análise dá a esse termo, ou seja, a transformação produzida no sujeito quando ele assume uma imagem cuja predestinação para esse efeito de fase é suficientemente indicada pelo uso, na teoria, do antigo termo imago (Lacan 1998, p. 97).

6 "Para designar a estrutura de reconhecimento que caracteriza ao efeito ideológico, chama a 'relação especular dual', expressão
}

sua eficácia, é necessário situá-la na superestrutura, e dar-lhe uma relativa autonomia com respeito ao direito e ao Estado" (Althusser 1977, p. 49).

Nesse artigo Althusser deixa bem claro que no plano da ideologia em geral há uma diferenciação entre as ideologias por serem representações de diferentes classes (burguesia, pequena burguesia, proletária). Entretanto, como ele observa, no modo de produção capitalista as ideologias pequeno burguesa e proletária são ideologias subordinadas, já que a ideologia burguesa é a predominante; mesmo diante o protesto das ideologias subordinadas, é ela quem as domina (pensemos no caso das ideologias espontâneas das classes exploradas) (idem, p. 55).

Daí a necessidade da transformação da ideologia da classe operária: de uma transformação que retire a ideologia da classe operária da influência da classe burguesa, para submetê-la "a uma nova influência, a da ciência marxista da sociedade. É precisamente neste ponto onde está fundamentada e justificada a intervenção da ciência marxista no movimento operário. E é a natureza mesma da ideologia e de suas leis a que determina os meios apropriados para assegurar a transformação da ideologia 'espontânea' reformista do movimento operário numa nova ideologia, de caráter científico e revolucionário" (idem, p. 3). A ciência marxista, para Althusser não tem um papel "neutro", pois, ao contrário, ela também age no campo ideológico para a formação de uma ideologia revolucionária e de ruptura.

Althusser voltaria a abordar de modo sistemático o conceito de ideologia em 1969, no seu manuscrito, parcialmente inédito, Sobre a reprodução,cujo título original seria "Sobre a reprodução das relações de produção", cujo célebre artigo "Ideologia e aparelhos ideológicos de Estado"foi extraído e publicado na revista La Pensée, em 1970. No manuscrito (como no artigo), Althusser mantém a definição da eternidade da ideologia (omni-histórica) e da relação imaginária dos indivíduos com as condições reais de existência, i.e., no plano do inconsciente. Além disso, assume explicitamente a influência da psicanálise na sua teoria (Althusser 1999, pp. 196-198) ${ }^{4}$. No entanto, Althusser incorpora novas observações sobre esse conceito ao introduzir a materialidade da ideologia como prática, sobretudo no que concerne a seu efeito interpelatório da ideologia na constituição dos sujeitos, e na sujeição destes ao Sujeito.

No manuscrito/artigo Althusser emite duas teses conjuntas: (i) toda prática existe por meio de e sob uma ideologia e (ii) toda ideologia existe pelo sujeito e para o sujeito (idem, p. 209). O sujeito, para Althusser, tem uma clara influência da psicanálise lacaniana, em particular O estádio do espelho como formador da função do $\mathrm{eu}^{5}$, como bem observa Ípola ${ }^{6}$. O sujeito na perspectiva althusseriana é tanto o sujeito da ação como também, ao mesmo tempo, o sujeito sujeitado a outro Sujeito (com s maiúsculo) que vem a ser uma ideologia, i.e, as crenças políticas, culturais, religiosas, esportivas etc., que todos os sujeitos individuais possuem. Não há, para Althusser, indivíduo, noção ideológica constituída pela modernidade capitalista, mas sim sujeitos: o indivíduo é sempre um sujeito desde o seu nascimento quando lhe é conferido um significado (um nome), e não é dotado de uma consciência autônoma já que é sempre sujeitado a algo (um Sujeito) que o interpela cotidianamente, sem que perceba a existência desse mecanismo de sujeição que, em última instância, reproduz as relações de poder. Há sempre, de acordo com Althusser, o mecanismo de reconhecimento-desconhecimento na constituição dos sujeitos pelas interpelações: o sujeito reconhece-se em um discurso, mas desconhece esses mecanis- 
inspirada em Lacan que remete as teses sobre o estádio do espelho" (Ípola 2007, p. 139).

${ }^{7}$ Essa citação do artigo publicado em 1970 é ligeiramente diferente da versão do manuscrito: em vez de quatro itens, Althusser cita apenas três (não há o item 2) e o quarto (3 no manuscrito) contém outro texto que vem a ser este: "3) a garantia absoluta de que tudo está bem assim: Deus é realmente Deus, Pedro é realmente Pedro e, se o submetimento dos sujeitos ao Sujeito for realmente respeitada, tudo decorrerá da melhor forma para eles: serão 'recompensados'" (Althusser 1999, p. 219). mos interpelatórios dos quais reproduz (ou transforma) as relações de poder da sociedade.

Há, portanto, uma dupla relação especular entre os sujeitos. Como afirma Althusser: "Isso significa que toda a ideologia tem um centro, que o Sujeito Absoluto ocupa o lugar único do centro e interpela à sua volta, a infinidade dos indivíduos como sujeitos, em uma dupla relação especular tal que ela submete os sujeitos ao Sujeito, ao mesmo tempo em que lhes dá, pelo Sujeito no qual todo sujeito pode contemplar sua própria imagem (presente e futuro), $a$ garantia de que se trata realmente deles e Dele e de que, passando-se tudo em família (a Sagrada Família: a Família é, por essência, sagrada). [...] Portanto, a estrutura duplamente especular da ideologia garante simultaneamente: 1) a interpelação dos indivíduos como sujeitos; 2) sua submissão ao Sujeito; 3) o reconhecimento mútuo entre os sujeitos e o Sujeito, e entre os próprios sujeitos, e o reconhecimento do sujeito por si mesmo; 4) a garantia absoluta de que tudo está bem assim, e sob a condição de que tudo está bem assim, e sob a condição de que se os sujeitos reconhecerem o que são e se conduzirem de acordo tudo irá bem: 'assim seja'" (Althusser 1976, pp. 118-119) ${ }^{7}$.

A definição de sujeito por Althusser é completamente distinta da de Lukács: enquanto para o filósofo húngaro permanece no sentido que lhe confere o pensamento moderno sobre o Sujeito centrado, Althusser, por seu turno, demarca um novo sentido no pensamento marxista: o sujeito é descentrado já os sujeitos são constituídos por vários e diferentes Sujeitos. Cada sujeito está submetido a diversas (quando não, adversas) ideologias relativamente independentes. Cada sujeito vive, então, simultaneamente, em e sob várias ideologias cujos efeitos de submetimentos "combinam-se" em seus próprios atos, inscritos em práticas, regulamentados por rituais. As interpelações discursivas constituem em cada "indivíduo" uma pluralidade de sujeitos, e se reconhece em distintos Sujeitos.

A despeito das semelhanças entre Lacan e Althusser sobre o sujeito descentrado, em oposição ao sujeito central definido pela filosofia moderna, Pascale Gillot aponta as diferenças entre o sujeito definido por Lacan e o de Althusser: "[...] uma divergência crucial entre os enfoques althusseriano e lacaniano, não é outro que a distinção conceitual que convém estabelecer entre o sujeito e o eu. Lacan mantém e incessantemente reafirma esta distinção, em particular através da concepção do sujeito como sujeito do inconsciente, e da diferenciação da ordem simbólica e imaginária que rege o eu. Em Althusser, pelo contrário, esta distinção conceitual não parece tematizada como tal. $\mathrm{O}$ sujeito interpelado às vezes parece reduzido a um eu, por certo que descentrado, submetido e privado do seu caráter esclarecedor da consciência, mas cujas opacidades são precisamente as falsas evidências da consciência" (Gillot 2010, p. 121).

Apesar da ênfase que dá, em seu texto, sobre o aspecto reprodutor da ideologia, Althusser reconhece que a ideologia política revolucionária, de corte marxista-leninista como ele destaca, apresenta a particularidade, sem qualquer precedente histórico, de ser uma ideologia fortemente "trabalhada", portanto transformada por uma ciência, a ciência marxista da História, das formações sociais, da luta de classes e da Revolução, o que "deforma" a estrutura especular da ideologia sem suprimi-la completamente. O paradoxo dessa afirmação de Althusser é o fato de não reconhecer que a relação especular também poderia ocorrer em uma ideologia revolucionária com perspectiva de ruptura em 
${ }^{8}$ Isabelle Garo, equivoca-se quando afirma que Althusser retoma de Foucault a politização das estruturas e descentrando a política. Na verdade é o inverso, pois o enfoque de Foucault sobre o poder das instituições foi bem explorado na sua obra Vigiare punir que é posterior ao artigo de Althusser (Garo 2008, p. 47).

${ }^{9}$ Não se tratará diretamente do texto de Albuquerque porque em grande parte ele reproduz os chavões de funcionalismo na obra de Althusser, extraídos de Poulantzas. Sobre os limites de Foucault (de quem Albuquerque calca-se em grande parte na sua "crítica") diante de Althusser sobre os conceitos de ideologia e de topologia, ver Zizek (1996, p. 19).

${ }^{10}$ Em 1969, Rancière escreveu que "'a análise da Universidade ensinou-nos que a ideologia de uma classe existe também, ou melhor, existe principalmente em instituições, naquilo a que podemos chamar os aparelhos ideológicos (no sentido em que a teoria marxista fala de aparelho de Estado)" (Rancière 2011, p. 250)

${ }^{11}$ Como o próprio Rancière ressalta no novo prefácio da edição de 2011 (Rancière 2011, p. 13). relação às estruturas de poder que reproduzem as relações de produção, como bem observa Laclau (1979, p. 107). Veremos isso na seção seguinte.

Ainda sobre os aparelhos ideológicos de Estado, é interessante notar que há um desnível no que é tratado sobre esse conceito no manuscrito em relação ao artigo. De fato, Althusser tece inúmeras observações e análises sobre os aparelhos de Estado na versão original que foram completamente suprimidas no artigo. A análise de Althusser sobre os aparelhos no artigo sempre foi tida como inferior quando comparada à da ideologia, vista como uma releitura das observações prévias de Gramsci sobre o papel da sociedade civil e da sociedade política na superestrutura. $\mathrm{O}$ que de fato ocorre é que Althusser redefine conceitualmente o Estado moderno (capitalista) ao alargá-lo, não se restringindo a esfera pública e as funções jurídicas e repressoras, tampouco restrito à tripartição de poderes. Como observa Antonio Negri o alargamento das funções do Estado por Althusser representa uma ruptura conceitual com o Estado moderno, embora Negri o defina de modo impreciso como "pós-moderno". Esta imprecisão deve-se pela ênfase da luta de classes por Althusser nos aparelhos de Estado, o que inexiste na perspectiva pós-modernista (Negri 1993, p. $82)^{8}$.

Uma das críticas mais frequentes é a acusação de que a teoria dos AIE seria de teor funcionalista e formalista, sobretudo pela pouca ênfase dada sobre a luta de classes. Isso fica nítido nas análises de Rancière (2011), Poulantzas (1978), Badiou e Balmès (1976), Cardoso (1977) e Albuquerque ${ }^{9}$ (1983). Poulantzas e Rancière ${ }^{10}$ disputam diretamente com Althusser a "paternidade" dos conceitos de Aparelho Ideológico e Aparelho Repressivo de Estado. Poulantzas começou a empregar esses conceitos em 1969 no artigo "O problema do Estado capitalista". O próprio Althusser cita, em alguns trechos do manuscrito,a contribuição de Poulantzas à teoria do Estado (embora não cite o conceito de aparelho ideológico de Estado), e que foram omitidos na versão do artigo. Em Fascismo e ditadura, Poulantzas ao empregar os conceitos de AIE e ARE, delimita suas diferenças com Althusser: "Penso que este texto de Althusser peca, em certa medida, pela sua abstração e pelo seu formalismo: a luta de classes não ocupa nele o lugar que de direito lhe cabe. [...] esta análise é abstrata e formal, na medida em que não toma (concretamente) em consideração $a$ luta de classes: [...] não toma em consideração o fato da existência, numa formação social, de várias ideologias de classe contraditórias e antagônicas" (Poulantzas 1978a, p. 323, p. 327).

Rancière, por sua vez, faz uma intensa crítica à Althusser na questão relacionada à oposição ciência $\mathrm{x}$ ideologia, o que para ele constitui uma ausência do papel da luta de classes, como também das contradições. Articulando uma posição política maoísta ${ }^{11}$ com preceitos foucaultianos, Rancière demarca, ao longo do texto, a ciência como um campo do poder/saber: "fala-se da ideologia de uma sociedade de classes, não da ideologia de classes. [...] O caráter científico do saber em nada afeta o conteúdo de classe do ensino. A ciência não surge face à ideologia como o seu outro: surge no interior das instituições e nas formas de transmissão do saber em que se manifesta a dominação ideológica da burguesia. [...] Os conhecimentos científicos são transmitidos por meio de um sistema de discursos, de tradições e de instituições que constituem a própria existência da ideologia burguesa. [...] Não existe uma ciência burguesa e uma ciência proletária: existe sim um saber burguês e um saber proletário" (Rancière 2011, pp. 223-234; p. 237). 
Já Badiou (em colaboração de François Balmés), no auge da sua militância maoísta, também teceu duras críticas (tal qual Rancière) ao "revisionismo" de Althusser, já que a sua concepção de ideologia, além de não ser dialética, trata a ideologia no plano imaginário e do inconsciente. Badiou ratifica, ao longo desse livro, que a ideologia pertence ao plano consciente dos sujeitos - de certa inspiração sartreana nesta fase - no qual as classes revolucionárias constituem-se para um projeto de ruptura: "os explorados forjam sua consciência na cotidianidade da própria exploração, e não nos meandros do imaginário. [...] Mas justamente, nos teóricos da ideologia como 'lugar imaginário' e 'interpelação do Sujeito' são aqueles mesmos que recusam a clareza dessa luta [...]. A verdade é que os maoístas e a vanguarda do movimento estudantil têm acusado Althusser de teoricismo durante todo o curso de ruptura de maio de 68; que por teoricismo entendíamos então, mais precisamente, a impossibilidade onde se encontrava em Althusser de articular corretamente as questões da ciência e da ideologia sobre aquelas da luta de classes. [...] a doutrina althusseriana da ideologia que a reduziu a um mecanismo de ilusão, sem que seja tomado em conta o conteúdo de classe real cuja toda formação ideológica não é mais do que a expressão contraditória" (Badiou \& Balmés 1976, p. 16; p. 20; p. 23; p. 27).

Althusser rebate essas críticas em um artigo de 1976 (particularmente Poulantzas e Badiou) ao negar o funcionalismo do seu artigo (embora reconheça o tom formalista, já destacado por ele mesmo no início do artigo) devido à ênfase em que dá à primazia da luta de classes sobre as funções e o funcionamento dos aparatos estatais. Ademais, também admite que, se os aparelhos ideológicos de Estado têm a função de inculcar a ideologia dominante, isso significa que existe resistência, e se há resistência é que há luta como resultado direto ou indireto da luta de classes; significa, portanto, que a ideologia proletária é uma ideologia de massas, capaz de unificar a vanguarda da classe operária em suas organizações de luta de classe.

Como o próprio Althusser adverte: "a ideologia dominante nunca é um fato consumado da luta de classes que tivesse escapado à luta de classes. Efetivamente, a ideologia dominante, que existe no complexo sistema dos Aparelhos Ideológicos de Estado, é em si mesma o resultado de uma dura e muito longa luta de classes, através da qual a burguesia não chega a atingir seus objetivos a não ser com a dupla condição de lutar, simultaneamente, contra a antiga ideologia dominante que sobrevive nos antigos Aparelhos e contra a ideologia da nova classe explorada que procura suas formas de organização e de luta. [...] a reprodução da ideologia dominante não é a simples repetição, não é uma simples reprodução, nem tampouco uma reprodução ampliada, automática, mecânica de determinadas instituições, definidas, de uma vez para sempre, por suas funções, mas o combate pela reunificação e a renovação de elementos ideológicos anteriores, desconexos e contraditórios, em uma unidade conquistada na e pela luta de classes, contra as formas anteriores e as novas tendências antagônicas. A luta pela reprodução da ideologia dominante é um combate inacabado que deve ser sempre retomado e está sempre submetido à lei da luta de classes" (Althusser 1999, pp. 239-240).

O partido revolucionário também efetivamente está permeado de ideologia, mas de uma ideologia revolucionária, na qual a sua forma interpelatória constitui sujeitos de ação de ruptura contra o sistema capitalista, e não de sujeição às instituições modernas burguesas. Conforme observa Althusser "para existir como classe consciente de sua unidade e ativa em sua organização de luta, o proletariado tem necessidades não só da experiência, mas também de conhecimentos objetivos, cujos princípios lhe são fornecidos pela teoria marxista. É a 
${ }^{12}$ Em um rápido mapeamento desse livro, Althusser fala da luta de classes (incluindo a questão da Revolução e da ditadura do proletariado) nas seguintes páginas da edição brasileira: $29,54,65-$ $69,74,97,100-102,107,110$, $112-113,115-117,119,121-131$ $133,135-142,144-152,154-163$, $166,173-174,176,178-179,180-$ $185,193,220,231$ e 233 . partir da dupla base dessas experiências, iluminadas pela teoria marxista, que se constitui a ideologia proletária, a ideologia das massas, capaz de unificar a vanguarda da classe operária em suas organizações de luta de classe. Trata-se, portanto, de uma ideologia muito particular: é ideologia, uma vez que a nível das massas funciona como qualquer ideologia (interpelando os indivíduos como sujeitos), mas impregnada de experiências históricas, iluminadas por princípios de análise científica" (Althusser 1999, pp. 248-249; grifos no original).

De fato, se Althusser tivesse publicado na íntegra a versão original, muitas das críticas sobre a fragilidade da teoria dos aparelhos ideológicos, e da ausência da luta de classes, teriam caído por terra (pelo menos em grande maioria). A maior parte do manuscrito que ficou inédita tratava diretamente dos aparelhos ideológicos de Estado, abordando não somente o papel das escolas, mas também do Direito (dois capítulos tratavam dessa problemática), dos aparelhos ideológicos político e sindical (incluindo um capítulo específico sobre eles na formação social francesa), dos aparelhos ideológicos na fase de transição revolucionária (onde ilustra como exemplos a Revolução Francesa de 1789 e a Revolução Russa de 1917), além de diversas passagens em que trata da luta de classes nos aparelhos ideológicos ${ }^{12}$.

Como é de amplo conhecimento, Althusser distingue os AIE dos ARE devido aos primeiros além de haver o predomínio da prática ideológica sobre a repressiva (que também está presente nos AIE), há uma multiplicidade e diversidade dos AIE em relação aos ARE. Não se trata, portanto, da diferenciação jurídica entre eles (se os AIE são "privados" e os ARE "públicos"). Essa é uma distinção de caráter jurídico, mas não das práticas. Para Althusser, o que faz um AIE é um sistema complexo que compreende e combina várias instituições e organizações, e respectivas práticas. Como ele afirma "que sejam todas públicas ou todas privadas, ou que umas sejam públicas e outras privadas, trata-se de um detalhe subordinado, já que o que nos interessa é o sistema que constituem. Ora, esse sistema, sua existência e sua natureza não devem nada ao Direito, mas a uma realidade completamente diferente que designamos por Ideologia de Estado" (idem, p. 108). Em uma posição bem distinta (e adversa) da corrente funcionalista, Althusser afirma que não são as instituições que "produzem" as ideologias correspondentes; pelo contrário, são determinados elementos de uma Ideologia (a Ideologia de Estado) que se "realizam" ou "existem" em instituições correspondentes, e suas práticas (Althusser 1999).

A ideologia não existe nas idéias. A ideologia pode existir sob a forma de discursos escritos ou falados que, supostamente, veiculam "idéias". Mas justamente a "idéia" que se faz das "idéias" comanda o que se passa nesses discursos. As "idéias" não têm de modo algum uma existência ideal, mas uma existência material. A ideologia não existe no "mundo das idéias", concebido como "mundo espiritual", mas em instituições e nas práticas próprias dessas mesmas instituições. A ideologia existe em aparelhos e nas práticas próprias desses mesmos aparelhos. É nesse sentido que os AIE concretizam, no dispositivo material de cada um deles e nas suas práticas, uma ideologia que lhes é exterior, denominada por Althusser por ideologia primária e pode ser chamada pelo nome de ideologia de Estado, unidade dos temas ideológicos essenciais da classe dominante ou das classes dominantes (idem, pp. 178-179).

Se a escola foi o principal foco do texto publicado em 1970, o Direito, que praticamente não foi abordado, tem um grande destaque no texto original publicado postumamente. O Direito é definido por Althusser como um espaço 
intermediário entre a repressão e a ideologia. Althusser entende por direito a Grundnorm positivista de Kelsen, na medida em que o Direito forma um sistema não contraditório e saturado, caracterizado pelo seu aspecto formal e não moral. Como afirma Althusser, "o formalismo do direito não tem sentido a não ser enquanto se aplica a conteúdos definidos que estão necessariamente ausentes do próprio direito. Esses conteúdos são as relações de produção e seus efeitos"(idem, p. 85). Isto significa dizer que o Direito exprime as relações de produção, embora, no sistema de suas regras, não faça qualquer menção às citadas relações de produção; ao contrário, escamoteia-as. Nesse aspecto, Althusser segue de perto as afirmações e Marx em Crítica do Programa de Got$h a$, em que aponta os efeitos da universalização da igualdade formal em uma sociedade desigual no tocante ao trabalho: "Esse igual direito é direito desigual para trabalho desigual. Ele não reconhece nenhuma distinção de classes. [...] Segundo seu conteúdo, portanto, ele é, como todo direito um direito da desigualdade" (Marx 2012, p. 31).

O Direito, por expressar a coerção por meio do Código Penal, atua diretamente no ARE, a exemplo da polícia, tribunais, multas e prisões. Contudo, o Direito como coação não se confunde com a ideologia jurídica. A ideologia jurídica retoma realmente as noções de liberdade, igualdade e obrigações, e inscreve-as fora do Direito, i.e., fora do sistema de regras do Direito e de seus limites, em um discurso ideológico que é estruturado por noções completamente diferentes. Enquanto o Direito diz: os indivíduos são pessoas jurídicas juridicamente livres, iguais e com obrigações como pessoas jurídicas, a ideologia jurídica faz um discurso aparentemente semelhante, mas de fato completamente diferente. Ela diz: os homens são livres e iguais por natureza. Na ideologia jurídica é, portanto, a "natureza", e não o Direito, que "fundamenta" a liberdade e igualdade dos "homens" (Althusser 1999, pp. 93-94). De qualquer maneira, Althusser não consegue definir claramente o aspecto ideológico do Direito quando atua de modo preventivo. Seria ou não condicionado pela ideologia jurídica? No capítulo XI do manuscrito ele tenta, de certa forma, resolver esse problema.

Em duas passagens Althusser elucida essa concepção abstrusa do Direito: "vimos que o direito era necessariamente repressor e inscrevia a sanção do direito no próprio direito, sob a forma do Código Penal. Por esse motivo, pareceu-nos que o direito só poderia funcionar realmente sob a condição da existência real de um Aparelho repressor de Estado que executasse as sanções formalmente inscritas no direito penal e pronunciadas pelos juízes dos tribunais [...]. Mas, ao mesmo tempo, pareceu-nos que, na imensa maioria dos casos, o direito era 'respeitado' pelo simples jogo combinado da ideologia política + um suplemento de ideologia moral, portanto, sem intervenção direta do destacamento do ARE especializado [...] se retivermos o fato de que o direito 'funciona' de maneira prevalecente por meio da ideologia jurídico-moral, apoiada por intervenções repressoras intermitentes; se, enfim, nos lembrarmos que defendemos a tese de que, em seu funcionamento, todo aparelho de Estado combina, simultaneamente, a repressão com a ideologia, temos fortes razões para considerara o 'direito'(ou antes, o sistema real que essa denominação designa, dissimulando-a, já que faz abstração da mesma, a saber: os Códigos + a ideologia jurídico-moral + a polícia + os tribunais e seus magistrados + as prisões, etc.) merece ser pensado sob o conceito de Aparelho Ideológico de Estado" (idem, p. 189; p. 192).

Embora Althusser permaneça com a afirmação de que a luta econômica seja a determinante em última instância, e a luta política seja central na estra- 


\footnotetext{
${ }^{13}$ É o caso das duas coletâneas organizadas por Caletti e Romé, onde em mais de dez artigos que abordam a problemática da ideologia em Althusser e dialogando com vários pensadores (Adorno, Badiou, Wittgenstein, Laclau, Voloshinov, Butler) não há nenhuma menção bibliográfica à versão do manuscrito.
}

tégia derradeira para o combate pelo poder de Estado, a luta ideológica, i.e., a luta de classes nos aparelhos de informação (luta pela liberdade de pensamento, de expressão, de difusão das idéias progressistas e revolucionárias) precede, em geral, as formas declaradas da luta política (idem, p. 180).

Interessante notar que as partes ausentes do artigo são marcadamente políticas, e acentuam em grande grau a posição leninista de Althusser, como bem observa Bidet na introdução da edição do manuscrito (Bidet 1999, p. 8). Devese também ressaltar que, a despeito de sua publicação desde os anos 1990, boa parte dos estudiosos de Althusser ainda prefiram apoiar-se teoricamente na versão do artigo $^{13}$. A versão do manuscrito, com efeito, é um preâmbulo da sua chamada "fase de autocrítica", que tem como marco inicial o texto "Resposta a John Lewis" de 1973, e dos textos da fase que podemos denominar a "crise do marxismo", que tem como ponto de partida o artigo "Enfim, a crise do marxismo", de 1977, e que abarca os textos de forte teor leninista-maoísta como Marxismo como teoria finita", O "22 congresso" e "O que não pode durar no partido comunista", publicados entre 1977 e 1978. Althusser demarca no capítulo X, "Reprodução das relações de produção e revolução" (totalmente excluído na versão de 1970), em vários momentos, a sua crítica ao partidoEstado e a defesa da ditadura do proletariado, e define o significado da revolução. Revoluções no sentido fraco são as que não afetam as relações de produção, portanto, o poder de Estado e o conjunto dos aparelhos de Estado, mas somente o aparelho ideológico de Estado político, a exemplo das revoluções de 1830 e 1848 na França. São simples modificações no aparelho ideológico político (como a formação da república parlamentar), acompanhadas por modificações em outros aparelhos ideológicos de Estado, a exemplo da escola. Revolução no sentido forte consiste, portanto, em desapossar a classe dominante no poder de Estado, i.e, da utilização de seus aparelhos de Estado que garantem a reprodução das relações de produção existentes, para estabelecer novas relações de produção cuja reprodução é garantida pela destruição dos antigos aparelhos de Estado e a edificação de novos aparelhos de Estado. Os exemplos citados por Althusser nesse caso é o da Revolução francesa de 1789, a Revolução socialista russa de 1917 e a Revolução chinesa de 1949 (Althusser 1999, p. 173).

Apesar de Althusser não ter mais escrito nenhum trabalho específico sobre o conceito de ideologia depois da resposta aos seus críticos em 1976, ele manteve suas posições teóricas e políticas como pode-se perceber na sua derradeira entrevista dada a Fernanda Navarro, publicada em 1988. Não obstante, no contexto dessa entrevista, tenha mudado algumas de suas posições teóricas pretéritas, devido a sua ênfase no materialismo aleatório (ou do acaso) em relação às determinações das estruturas que caracterizaram os seus escritos iniciais, sua atitude diante ao conceito de ideologia manteve-se inalterável. Conforme nota-se na entrevista, Althusser ainda define a ideologia como uma prática na qual, por meio das interpelações, constituem sujeitos em uma relação imaginária com as suas condições reais de existência. "O homem sempre tem vivido sobre relações sociais ideológicas" e "os indivíduos são desde sempre, sujeitos, quer dizer, sujeitos-já-sujeitados por uma ideologia" (Althusser 1988, p. 65). Além disso, Althusser mantém o papel dos aparelhos ideológicos haja vista que a existência social das ideologias é inseparável das instituições por meio das quais se manifestam, com seu código, sua língua, seus costumes, rituais e cerimônias.

Como dissemos no início do artigo, a influência de Althusser foi decisiva na elaboração do conceito de ideologia, e sua influência é perceptível no deba- 
te sobre o tema desde o fim dos anos 1960. E Ernesto Laclau é uma das principais expressões da influência de Althusser como veremos na seção seguinte.

\section{Laclau: da teoria da ideologia marxista ao pós-marxismo discursivo}

A intervenção de Laclau ao debate sobre o conceito de ideologia foi marcada por sua contribuição à nova definição que ele deu à ideologia nacionalistapopulista, de corte de esquerda, bastante presente na realidade latino-americana dos anos 1960-1970 a exemplo do governo peruano de Velasco Alvarado, da esquerda peronista (Montoneros), da esquerda varguista (brizolismo), dos Sandinistas etc., sem falar das experiências pan-arabistas que ocorriam no Oriente Médio e no norte da África (sobretudo na Argélia). Sua contribuição a esse tema fez de Laclau um dos intelectuais mais criativos da corrente marxista althusseriana.

A obra de Laclau pode ser dividida em quatro fases, como aponta Maria Martina Sosa: (i) uma primeira aproximação profundamente marcada pela influência althusseriana e, sobretudo, pelos conceitos de sobredeterminação e interpelação apresentados no livro Política e ideologia na teoria marxista, de 1977; (ii) a ênfase na lógica do significante e as posições do sujeito em Hegemonia e estratégia socialista, de 1985; (iii) a importância do Real e a vinculação entre a categoria de sujeito e o espaço político nos artigos escritos nos anos 1990, e reunidos nos livros como Emancipação e diferença, de 1996, e Misticismo, retórica e política, de 2002; (iii) a preocupação pelo investimento afetivo na constituição dos sujeitos políticos e sua relação tanto com a noção de identificação como a lógica do objeto em A razão populista, de 2005 (Sosa 2011, pp. 168-169).

Em sua primeira fase, na qual teve como base teórica o marxismo althusseriano e a psicanálise lacaniana, Laclau fez acréscimos à definição que Althusser deu ao conceito de ideologia. Tendo como eixo central os conceitos de sobredeterminação e interpelação de Althusser, Laclau constrói sua análise sobre o populismo nacionalista em uma concepção anti-reducionista, e anti-essencialista, em clara oposição à concepção lukásciana. Como o próprio Laclau observa, não podemos conceber a superestrutura (a ideologia, como também o Estado) de forma reducionista às classes sociais, já que não podemos pensar a existência das classes aos níveis políticos e ideológicos sob a forma de redução. Isso significa afirmar que o caráter de classe de uma ideologia é dado pela sua forma, e não pelo seu conteúdo (Laclau 1979).

O exemplo que Laclau nos dá é a ideologia nacionalista. Para determinados setores de esquerda, e pensamos nesse caso o trotskismo, o nacionalismo sempre foi rotulado de ideologia burguesa na qual impedia a formação da consciência da classe proletária. A mesma interpretação foi evocada por "liberais de esquerda" como Weffort (1978), que, além disso, afirmava ser o nacionalismo uma expressão de uma ideologia pequeno burguesa que consagrava o Estado. $\mathrm{O}$ que podemos perceber, a partir de Laclau, que o nacionalismo (como o populismo), enquanto ideologia, foi articulada por diferentes classes sociais. $\mathrm{O}$ nacionalismo pode ter uma conotação expansionista e agressiva, como no caso da Alemanha de Bismarck e no contexto nazista, como também de teor antiimperialista, a exemplo do maoísmo na China, do castrismo em Cuba, e de diversas facções da esquerda peronista armada, como também de intelectuais militantes no campo do peronismo, como podemos ver nas obras de John William Cooke, Hernandez Arrégui, Abelardo Ramos e Norberto Galasso. Tam- 
bém podemos classificar de nacionalismo antiimperialista o nasserismo dos anos 1950 de forte influência não somente na África e Oriente Médio, mas também em militares da América Latina, como o já citado Velasco Alvarado do Peru, mas também Omar Torrijos do Panamá.

O que importa salientar aqui é a contribuição de Laclau ao conceito de ideologia althusseriano com a incorporação do principio articulatório nas interpelações. Isso significa afirmar que, enquanto, na infraestrutura, a contradição principal é entre as relações de produção e as forças produtivas, e as classes estão em forma de redução, na superestrutura as classes são amplas e estão sob a forma de articulações, e a contradição principal é entre o povo e o bloco no poder, contradição esta sobredeterminada pela contradição fundamental, i.e, entre as relações de produção e as forças produtivas. Se na infraestrutura (ou no modo de produção) há luta de classes, na superestrutura (pensando em uma formação social específica) há classes em luta (Laclau 1979, pp. 107-108).

Segundo Laclau "se a contradição de classe é a contradição dominante ao nível abstrato do modo de produção, a contradição povo/bloco no poder é a contradição dominante ao nível da formação social. [...] se nem toda contradição pode ser reduzida a uma contradição de classes, toda contradição é sobredeterminada pela luta de classes. [...] A luta de classes a nível ideológico consiste, em grande parte, no esforço em articular as interpelações populardemocráticas aos discursos ideológicos das classes antagônicas" (idem, p. 114).

O princípio articulatório, como define Laclau, visa à condensação de diferentes ideologias de classes (e não classistas como o nacionalismo e o populismo) antagônicas entre si, mas que são unificadas por uma contradição antagônica, e sobredeterminante na formação social, que é a contradição povo em oposição ao bloco no poder. É a partir dessa condensação desses elementos dispersos em diversas ideologias que Laclau considera a possibilidade da formação de uma hegemonia. Para Laclau, seguindo as teses de Althusser, uma classe dominante interpela não somente os seus membros dessa classe, mas também os membros das classes dominadas. A interpelação dessas últimas consiste na absorção parcial e neutralização dos conteúdos ideológicos através dos quais se expressa a resistência e dominação. No caso contrário, vindo dos setores dominados, é a acentuação desses elementos para aguçar o antagonismo com o bloco no poder. Uma classe é hegemônica não porque é capaz de impor uma concepção uniforme de mundo ao resto da sociedade, mas que consiga articular diferentes visões de mundo de forma tal que seu antagonismo potencial seja neutralizado, ou potencializado quando visa uma ruptura. Portanto, a classe hegemônica exerce sua hegemonia de duas maneiras: (i) através da articulação, ao seu discurso de classe, das contradições e interpelações não classistas; (ii) através da absorção de conteúdos que fazem parte do discurso político e ideológico das classes dominadas (idem, p. 113; p. 171; p. 172).

Um dos aspectos mais significativos nessa análise de Laclau é o papel das tradições populares como um dos elementos ideológicos dessa articulação. Como ele diz, "se aceitamos a universalidade do critério de classe e, ao mesmo tempo, falamos em luta secular do povo contra a opressão, a ideologia em que esta luta secular se cristaliza só pode ser a de uma classe diferente da classe operária - uma vez que essa última surge somente com o industrialismo moderno. [...] As 'tradições populares' constituem o conjunto de interpelações que expressam a contradição povo/bloco de poder como distinta de uma contradição de classe. [...] Em primeiro lugar, na medida em que as 'tradições popula- 
res' representam a cristalização ideológica da resistência à opressão em geral, isto é, à própria forma do Estado, deverão ter maior duração do que as ideologias de classe e constituirão um marco estrutural de referência mais estável do que estas últimas. Entretanto, em segundo lugar, as tradições populares não constituem coerentes e organizados mas, puramente, elementos que só existem articulados a discursos de classe (idem, p. 173; grifos no original).

Há, então, nos discursos ideológicos de resistência e de mudança ao bloco no poder, elementos de tradições de luta popular que são incorporados em movimentos revolucionários, como podemos citar os exemplos dos Tupamaros, dos Sandinistas, dos Montoneros e dos Zapatistas. São elementos invariáveis, e que são sempre evocados como forma de mobilização contra o poder hegemônico das classes e dos grupos hegemônicos. O ponto de partida para Laclau, nessa questão, é o estudo sobre o conceito de ideologia feito por Badiou e Balmés (1976), no qual analisam os elementos invariantes das ideologias revolucionárias denominados por eles de invariantes comunistas.

Badiou e Balmés designam como invariantes comunistas a existência de toda revolta revolucionária das massas, qualquer que seja a época considerada de aspirações igualitárias, antiproprietárias e antiestatais. Esse interessante estudo de Badiou e Balmés tem como principal fonte o livro de Engels, A guerra dos camponeses na Alemanha, no qual o autor apresenta um intenso estudo sobre as revoltas camponesas do século XVI sob inspiração da teologia revolucionária de Thomas Münzer (Engels 2010). Laclau inspira-se em duas observações feitas por Badiou e Balmés (1976): a primeira diz respeito ao fato de que a ideologia dominante, para organizar as massas, não pode ignorar sua experiência cotidiana de opressão de classe. Todo seu esforço tende, portanto, a reabsorver, não a contradição, mas seu antagonismo. Apresentar a contradição antagônica, que regula o movimento da história como simples diferença natural estruturante da identidade "eterna", o que é na verdade um momento da história. Para fazer de modo correto a inelutável exigência espontânea da redução das diferenças, toda ideologia dominante garante que, para além das diferenças concretas perdura, seja a título de promessa, uma igualdade abstrata.

A segunda corresponde às invariantes comunistas que de acordo com Badiou e Balmés "não têm um caráter de classe definido: elas sintetizam a aspiração universal dos explorados em oposição a todo princípio de exploração e de opressão. Elas nascem sobre o terreno da contradição entre as massas e o Estado. [...] Um certo tipo de comunismo coletivista surgiu inelutavelmente sobre a base das revoltas de massa, mesmo não proletárias. Na esfera ideológica, pensada com esfera contraditória, se desenvolve uma contradição relativamente invariante que opõe as idéias de tipo igualitário às idéias hierárquicas e desiguais" (idem, pp. 67-68).

De acordo com Badiou e Balmés (idem), as invariantes comunistas são sempre portadoras na história da revolta das classes exploradas, i.e., pela revolta dos produtores diretos: escravos, servos e proletários. As invariantes comunistas estão no curso da resistência ideológica contra a exploração em geral e às idéias que as servem. Elas refletem o movimento real pelo qual os explorados não se insurgem somente contra a forma específica de exploração do qual são vítimas, mas contra a idéia mesma de exploração (idem, p. 91). A universalidade das invariantes comunista dá-se sempre na especificidade das contradições de classe historicamente determinadas. Então, mesmo que ela desenvolva-se no elemento doutrinal da "profecia comunista", a revolta, com ex- 
periência real, toma posição sobre o caráter específico das contradições de classe (idem, p. 97).

A diferença entre Laclau e Badiou e Balmés é que, enquanto para estes o comunismo é o elemento invariante, para o primeiro o comunismo é uma das articulações possíveis dos elementos popular-democráticos. É a articulação que permite o desenvolvimento de todo antagonismo potencial da ideologia popular-democrática. E para Laclau a ideologia popular-democrática significa primeiramente que "o sujeito interpelado como 'povo' deve sê-lo em termos de uma relação antagônica face ao bloco de poder. E em segundo lugar, por democracia não entendemos nada que tenha uma relação necessária com as instituições parlamentares liberais. [...] Pelo contrário, em nossa concepção, a extensão real do exercício de democracia e a produção de sujeitos populares cada vez mais hegemônicos, são dois aspectos de mesmo processo" (Laclau 1979, p. 113).

Contudo, Laclau deu uma guinada na sua teoria política e sociológica ao escrever em parceria com Chantal Mouffe, em 1985, o livro Hegemonia e estratégia socialista. Nesse livro há uma forte influência do contexto da crise que atingiu o pensamento marxista, o malogro das experiências socialistas do Leste europeu, o declínio da social-democracia e do eurocomunismo, e a emergência do neoliberalismo e da ascensão dos novos movimentos sociais. Laclau muda de paradigma e de enfoque. Paradigma por romper com a teoria marxista e adotar o que ele denomina de "pós-marxismo". Enfoque por deixar de lado o conceito de ideologia (intensamente identificado com a teoria marxista) e adotar a categoria de discurso. Há a emergência de novos conceitos na sua teoria como sutura, lógica da equivalência e lógica da diferença, contingência, pontos nodais e significante vazio. Laclau, com efeito, a partir desse trabalho, aproximou-se de forma cada vez mais estreita com as correntes pós-modernista e pós-estruturalista (Foucault e Derrida, sobretudo), e cada vez mais abandonando as referências marxistas (Althusser e Gramsci, especialmente) que ainda se faziam presentes em 1985.

O ponto de partida para compreendermos essa nova posição teórica de Laclau é a crítica que ele estabelece às leituras topológicas da sociedade, na qual refuta qualquer possibilidade de determinação, mesmo sendo em última instância como ele afirmava anteriormente. O próprio conceito de sociedade é apontado por ele como uma impossibilidade epistemológica já que seria um equívoco "suturar" algo que não haja uma "essência" ou determinação devido a sua intensa fragmentação, e, além disso, Laclau demarca em sua análise de que o contingente (o acaso) sobrepõe-se à necessidade (as determinações). Como ele mesmo afirma, "não existe um espaço suturado que possamos conceber como uma 'sociedade', já que o social carece de essência" (Laclau \& Mouffe 2010, p. 132).

Para a constituição e organização das relações sociais fragmentadas em um determinado contexto sociopolítico, é necessária uma prática articulatória (estrutura discursiva). Por articulação Laclau denomina a toda prática que estabelece uma relação entre elementos, que a identidade destes resulta modificada como resultado dessa prática. A totalidade estruturada resultante da prática articulatória é denominada de discurso. Por momento Laclau chama as posições diferenciais como aparecem articuladas no interior do discurso. E, pelo contrário, por elemento a toda diferença que não se articula discursivamente (idem, p. 143). 
Inspirado em Foucault, a formação discursiva para Laclau caracteriza-se pela "regularidade na dispersão". Segundo Laclau "uma dispersão governada por regras pode ser vista de duas perspectivas opostas. Em primeiro lugar, enquanto dispersão; isto exige determinar o ponto de referencia a respeito do qual os elementos podem ser pensados como dispersos. Mas a formação discursiva pode ser vista também da perspectiva da regularidade na dispersão e pensar em tal sentido como conjunto de posições diferenciais. Este conjunto de posições diferenciais não é a expressão de nenhum princípio subjacente exterior a si mesmo [...], mas constitui uma configuração, que em certos contextos de exterioridade pode ser significada como totalidade. Dado que nosso interesse primário é nas práticas articulatórias, é neste segundo aspecto que devemos nos concentrar especialmente" (idem, pp. 143-144).

Laclau, então, observa que, com essa regularidade na dispersão, a contingência e a articulação são possíveis, visto que nenhuma formação discursiva é uma totalidade suturada, e porque a fixação dos elementos nos momentos nunca é completa. O que se segue é a seguinte afirmativa de Laclau e Mouffe: "nossa análise rechaça a distinção entre práticas discursivas e não discursivas e afirma: a) que todo objeto se constitui como objeto de discurso, na medida em que nenhum objeto se dá a margem de toda a superfície discursiva de emergência; b) que toda distinção entre os que usualmente se denominam aspectos lingüísticos e práticos (de ação) de uma prática social, ou bem devem ter lugar como diferenciações internas a produção social de sentido, que se estrutura sob a forma de totalidades discursivas" (idem, pp. 144-145).

A materialidade do discurso de Laclau e Mouffe pouco diferencia-se da materialidade ideológica althusseriana. Tal qual a ideologia, o discurso não provém da experiência, nem da subjetividade, mas tem uma existência objetiva haja vista que as diversas posições de sujeito aparecem dispersas no interior de uma formação discursiva. A segunda consequiência é que a prática da articulação como fixação-deslocação de um sistema de diferenças tampouco pode consistir em meros fenômenos lingüísticos, mas sim que deve atravessar toda a espessura material de instituições, rituais, práticas de diferente ordem, através das quais uma formação se estrutura.

A diferença é devida ao caráter absoluto que encontra o discurso em Laclau, já que em Althusser a prática discursiva (ideológica) é articulada com as outras práticas que atuam no todo complexo desigual e estruturado, correspondente ao modo de produção abstrato e a formação social concreta. De acordo com Laclau, é o discurso que contribui para moldar e constituir as relações sociais. Para ele, a principal conseqüência dessa definição é romper com a dicotomia discursiva/extradiscursiva é abandonar também a oposição pensamento/realidade e, consequentemente, ampliar imensamente o campo das categorias que podem dar conta das relações sociais. Essa afirmativa só se impõe se a lógica relacional o discurso realiza-se até suas últimas consequências e não é limitada por nenhuma exterioridade. Se uma totalidade discursiva nunca existe sob a forma de uma positividade simplesmente dada e delimitada, nesse caso a lógica relacional é uma lógica incompleta e penetrada pela contingência. A transição dos "elementos" aos "momentos" nunca se realiza totalmente. Cria-se assim uma terra do nada que faz possível a prática articulatória. Nesse caso não há identidade social que apareça plenamente protegida de um exterior discursivo que a deforma e a impede de suturar-se completamente. Perdem seu caráter necessário tanto as relações como as identidades. 
O que se conclui com essa perspectiva discursiva de Laclau é que "a sociedade" não é um objeto legítimo de discurso. Não há - como observam Laclau e Mouffe - "princípio subjacente único que fixe - e assim constitua - o conjunto do campo das diferenças. A tensão irresolúvel interioridade/exterioridade é a condição de toda prática social: a necessidade só existe como limitação parcial do campo da contingência. É no terreno desta impossibilidade tanto da interioridade como de uma exterioridade totais, que o social se constitui" (idem, p. 151). A hegemonia, distintamente da de Gramsci (1980) em que há um sujeito (o partido revolucionário que constrói a hegemonia da classe fundamental na sociedade civil), e que articula um projeto societal em direção à conquista do poder de Estado, em Laclau e Mouffe a hegemonia tem um caráter incompleto e aberto e só pode ser constituída em um campo geral das práticas articulatórias. Essa articulação de diferentes identidades e discursos é efetivada por um "ponto nodal", i.e, um ponto centralizador que articula esses elementos até então dispersos, mas articulados devido a seu antagonismo em comum a outro, este sendo definido como algo que impede a formação de uma lógica de equivalência identitária.

A hegemonia só pode resultar de uma dialética (ainda que peculiar) entre a lógica de equivalência e a lógica de diferença. Segundo Laclau e Mouffe, "os atores sociais ocupam posições diferenciais no interior daqueles discursos que constituem o serviço social. Em tal sentido elas são particularidades. Por outro lado, há antagonismos sociais que criam fronteiras internas a sociedade. É o caso das forças opressivas, por exemplo, um conjunto de particularidades estabelece entre si relações de equivalência. Resulta necessário, sem embargo, representar a totalidade desta cadeia mais além do particularismo diferencial dos laços equivalentes. Quais são os meios de representação? Como afirmamos, esses meios de representação só podem consistir numa particularidade cujo corpo se divide, dado que, sem cessar de ser particular, ela transforma o seu corpo na representação de uma universalidade que os transcende - a cadeia equivalencial. Esta relação, pelo que uma certa particularidade assume a representação de uma universalidade inteiramente incomensurável com a particularidade em questão, é o que chamamos de relação hegemônica. Como resultado, a universalidade é uma universalidade contaminada: (i) ela não pode escapar a esta tensão irresolúvel entre universalidade e particularidade; (ii) sua função de universalidade hegemônica não está nunca definitivamente adquirida, senão que é, pelo contrário, sempre reversível" (Laclau e Mouffe 2010, pp. 13-14; grifos no original). Esse caráter flutuante e contingencial da hegemonia acaba em resultar no conceito de significante vazio, o que significa que os grupos que disputam, em uma arena política, transformar a sua particularidade em um universal temporário, já que o universal não tem corpo e conteúdo necessário (Laclau 2011, p. 50, p. 78).

Antes de terminar esta seção é importante fazer uma análise do que Laclau e Mouffe (2010) definem o que seja marxismo, e sobre os limites da influência de Althusser nessa nova tomada de posição teórica. Primeiramente, é importante destacar que o marxismo abordado por Laclau e Mouffe em nada assemelha-se ao marxismo de Althusser, visto que o enfoque é dado ao marxismo essencialista de corte lukásciano, de teor humanista e historicista, antagônico ao defendido por Althusser e seus seguidores. Contudo, Laclau e Mouffe em nenhum momento estabelecem essa diferença. Ao contrário, tratam de forma homogênea, isso sem falar em um marxismo de corte mecanicista e determinista que eles citam ao longo da obra. O resultado disso é uma má compreensão do marxismo por parte de seus intérpretes no Brasil, que, diferentemente 
${ }^{14}$ Vide os artigos de Barciela (2011), Sosa (2011) e Burdman (2011).

${ }^{15}$ Concordamos plenamente com as observações de Lewis sobre essa questão em relação ao conceito de Althusser: "Sobredeterminação [em Althusser], ao contrário da definição Laclau e Mouffe, é sempre ligada ao real, e será conhecida através dos fenômenos que o real ou econômico produz. Ao removê-lo de sua base é uma má compreensão do termo e uma perda do seu significado" (Lewis 2005, p. 11).

\footnotetext{
${ }^{16}$ Escobar, ao analisar a crítica de Althusser a Engels nesse artigo, diz que "Althusser parece resistir à ousadia de Engels e tenta de alguma forma reabilitar o controle de uma dialética que se aspira um saber sem acasos. Ao dizer isso não estamos esquecendo que cabe a Althusser - mais do que a ninguém - o mérito de ter aproximado a dialética tanto de uma problematização aberta (a um materialismo dialético não platonicamente dialético) quanto a do acaso na categoria de sobredeterminação" (Escobar 1996, pp. 35-36).
}

da Argentina ${ }^{14}$, onde se busca essa influência de Althusser na teoria de Laclau, aqui associam mais a sua teoria com o pós-estruturalismo (Deleuze, Derrida e Foucault).

Laclau, com efeito, é o maior responsável por essa confusão. Além de classificar a teoria marxista de forma reducionista, emprega de modo impreciso os conceitos althusserianos como os de interpelação e sobredeterminação dos quais ele recorreu na sua fase inicial, e ainda reivindicava essa influencia no seu livro de 1985. Se a interpelação para Althusser é o mecanismo que materializa a ideologia nos sujeitos a partir dos aparelhos ideológicos, Laclau não aborda profundamente essa questão já que nem trata do papel dos aparelhos ideológicos, não obstante ainda que venha a reconhecer que a materialidade dos discursos advenha de rituais e práticas (embora ele não explicite sobre esses rituais e instituições no texto). Em relação ao conceito de sobredeterminação o equívoco é bem maior. Apesar de ter recorrido de modo preciso a esse conceito em sua análise inicial sobre o nacionalismo-populista, em Hegemonia e estratégia socialista, a sobredeterminação é empregada pelo viés psicanalítico (do qual se origina) na sua manifestação simbólica nas relações sociais (Laclau \& Mouffe 2010, p. 134). Althusser não aplica esse conceito no campo simbólico ou imaginário, mas sim no real. A sobredeterminação para Althusser manifesta-se pelo acúmulo de contradições oriundas das mais diferentes instâncias e, ao serem condensadas por uma contradição sobredeterminante, o antagonismo manifesta-se na forma de ruptura, como indica uma conjuntura revolucionária. É, para todos os efeitos, uma manifestação das estruturas e das práticas que estão articuladas de forma desigual no todo complexo estruturado (distinta da totalidade hegelo-lukasciana) definido por Althusser $(1986)^{15}$.

Um aspecto no mínimo curioso une Althusser a Laclau nesse livro, embora não tenha sido abordado, ou analisado, possivelmente por falta de informação por parte de Laclau: ao empregar o conceito de contingência, Laclau vai ao encontro do "último Althusser". A fase final de Althusser foi marcada por sua ênfase no aleatório, no contingencial, no acaso, o que ele veio a definir como uma tradição subterrânea da filosofia que ele denomina de "materialismo do encontro", tradição essa que engloba diferentes autores como Maquiavel, Hobbes, Spinoza, Rousseau, Marx, Heidegger e Derrida. De fato, como observa Ípola (2007), desde seus trabalhos publicados em Pour Marx, Althusser já percebia essa tensão entre o acaso e a necessidade. Isso fica nítido no anexo do artigo "Contradição e sobredeterminação", quando Althusser analisa, a partir da carta de Engels a Bloch, a relação do acaso com a necessidade (a determinação) ${ }^{16}$. Em um texto inédito escrito na primeira metade dos anos 1960, Sobre a gênese, Althusser (2012) também se reporta a relação das estruturas com o acaso. Além disso, Althusser, ao afirmar que o processo é sem sujeito e sem fim, dá clara margem para que o acaso seja um dos elementos desse processo não teleológico. Com a descoberta de vários textos inéditos de Althusser, Ípola afirma que paralelamente ao projeto declarado de Althusser (que é constituído pelos textos publicados em vida, definidos como "althusserianos"), existe um projeto subterrâneo no qual a questão do aleatório estava presente ${ }^{17}$.

Althusser delimita claramente essa posição do acaso nessa passagem em seu texto póstumo: "Diremos que o materialismo do encontro se sustenta também por inteiro na negação do fim, de qualquer teologia, seja racional, mundana, moral, política ou estética. Diremos, enfim, que o materialismo do encontro não é o de um sujeito (seja Deus ou o proletariado), mas o de um processo sem sujeito, que impõe aos sujeitos (indivíduos ou outros) aos quais domina a ordem de seu desenvolvimento sem fim definido" (Althusser 1994, 
17 "Importa, sem embargo, precisar que o projeto declarado e o 'projeto' subterrâneo não são sempre forçosamente contraditórios, nem sequer foram concebidos como instâncias antagônicas. Por certo a irrupção inopinada de enunciados 'fora de lugar' em plena elaboração de tal ou qual aspecto do projeto declarado gera um tipo de tensão, de inimizade inclusive, entre o pensamento elaborado e o enunciado 'transgressor' surgido abruptamente do nada; mas há também zonas na obra de Althusser em que as posições de um e outro se justapõem sem hostilidade" (Ípola 2007, pp. 40-41).

${ }^{18}$ Uma análise bem positiva ao livro de Laclau e Mouffe encontra-se em Barret (1996). p. 577). Apesar dessa aproximação de Althusser ao pós-estruturalismo, ele não negou o papel da luta de classes como Laclau. Em sua entrevista a Fernanda Navarro, Althusser afirmava "Se justamente a língua alemã dispõe de uma palavra precisa para designá-la: Geschichte que se refere já não a história consumada, mas sim a história no presente, sem dúvida determinada em grande parte pelo seu passado já acontecido, mas só em parte, porque a história presente, viva, está aberta também a um futuro incerto, imprevisto, ainda não consumado e portanto aleatório. A história viva que não obedece mais que a uma constante (não uma lei): a constante da luta de classes. [...] É dizer que uma tendência não possui a forma ou figura de uma lei linear, mas que pode bifurcar-se sob o efeito de um encontro com outra tendência e assim até o infinito. Em cada cruzamento de caminhos, a tendência pode tomar uma via imprevisível, aleatória" (Althusser 1988, p. 36).

Para finalizar, as teses de Laclau e Mouffe geraram intervenções, positivas e negativas, sobre a formação discursiva e o "pós-marxismo" ${ }^{18}$. Eagleton, por exemplo, critica Laclau e Mouffe (2010) pela aproximação da fluidez típica do pós-estruturalismo onde os conflitos (e a posição de dominante e dominado) tornam-se completamente relativos. Como observa Eagleton, "o princípio unificado não é mais a' economia' mas a própria força homogeneizadora, que mantém uma relação quase transcendental com os 'elementos' sociais que trabalha" (Eagleton 1997, p. 189). Essa volatilidade dos grupos faz com que não haja nenhum ponto situacional das classes e grupos, visto que o próprio conflito é disperso e contingente. O exemplo crítico de Eagleton é esclarecedor nesse aspecto: se os capitalistas monopolistas não têm interesses independentes da maneira como são politicamente articulados, então parece não haver nenhum motivo para que a esquerda política não deva despender enormes recursos de energia procurando conquistá-los para seu programa. O fato de que não o fazemos é porque consideramos que os interesses sociais dados dessa classe fazem que seja bem menos provável tornarem-se socialistas do que, digamos, os desempregados" (idem, p. 190).

Boron também tece severas críticas a Laclau e Mouffe na medida em que tentam criticar o "reducionismo econômico" do marxismo acabam por tecer uma perspectiva teórica do "reducionismo discursivo". Nessa concepção que, segundo Boron, retoma o idealismo transcendental em uma roupagem sociológica, o mundo exterior e objetivo de um discurso lógico que lhe infunde um sopro vital e que, de quebra, devora e dissolve a conflitividade do real. A exploração capitalista já não é resultado da lei do valor e da extração da maisvalia, mas só se configura se o operário pode representá-la discursivamente. Em outra passagem, Boron afirma que "Laclau e Mouffe estão corretos ao pronunciar, assim como numerosos teóricos marxistas, uma radical revalorização do crucial papel que à ideologia e à cultura assuntos pelos quais o marxismo vulgar demonstrou um injustificável desprezo. Entretanto, sua tentativa naufraga nos arrecifes de um 'novo reducionismo' quando a sua crítica ao essencialismo classista e ao economicismo do marxismo da Segunda e da Terceira Internacionais resulta na exaltação do discursivo, como um novo e hegeliano ex machina da história. Para a sua desgraça, não existe reducionismo 'bom' e outro 'mau'; não existe reducionismo virtuoso - não essencialista, não economicista - capaz de consertar os males ocasionados por seu irmão gêmeo rebelde" (Boron 2001, p. 150).

Como dissemos no início desta seção, a teoria de Laclau foi bastante abalada pela crise de conjuntura pelo qual passou os movimentos e organizações de esquerda, e principalmente o pensamento marxista, nos anos 1980. Não é ca- 
sual que ele e Mouffe afirmassem a predominância das bandeiras da liberdade sobre a igualdade, i.e, das demandas de caráter liberal em relação às de teor coletivo que sempre fizeram parte dos projetos da esquerda (Laclau \& Mouffe 2010, p. 208). No entanto, a obra de Laclau sofreu algumas mudanças recentes de enfoque, já que a problemática do populismo vem ocupando um espaço central nos seus últimos trabalhos. Ainda que a questão do populismo esteja sendo analisada a partir do prisma dos conceitos de lógica de equivalência e de diferença, de significante vazio, e de afetividade (Laclau 2005; 2009) há uma perceptível guinada para a esquerda, possivelmente motivado pelo avanço recente da esquerda (particularmente na América Latina) diante da crise do projeto neoliberal. Isso também fica nítido na sua aliança com Badiou e Rancière na defesa do conceito de povo (que constitui um discurso igualitário) em relação ao de "multidão" (que afirma as diferenças) apregoado por Antonio Negri, como também a sua justa crítica à noção de Império de Negri e Hardt, e na defesa do conceito de imperialismo (Laclau 2008, p. 134). Ademais, Laclau retomou ao conceito de ideologia em obra recente (Laclau 2002), embora esse conceito não ocupe mais um lugar central em sua teoria tal como foi na fase inicial de sua obra. E ao que parece, alguns elementos "contingenciais" que ainda estão por vir possam mudar e fixar uma posição mais radical, de novo, na teoria política de Laclau.

\section{Conclusões}

Como foi visto ao longo deste artigo, Althusser redefiniu o significado do conceito de ideologia não somente no pensamento marxista (ao refutar o significado da ideologia enquanto falsa consciência, ou mera expressão de um contexto histórico) mas também nas Ciências Sociais em geral, ao aproximar-se da psicanálise freudo-lacaniana e definir a ideologia como uma prática que tem como efeito materializar a representação da relação imaginária dos sujeitos individuais com suas condições reais de existência. Isso deu um novo significado a esse conceito que em muitas de suas leituras no marxismo conferiamlhe um sentido negativo. E ao tratá-lo como uma estrutura não o limitou a circunstâncias históricas, ou a ideologias particulares.

Essa definição de ideologia por Althusser foi fundamental na obra inicial de Laclau quando este deu um novo significado ao conceito de populismo (e de nacionalismo), a partir do princípio articulatório por meio das interpelações. Todavia, com a crise do paradigma marxista nos anos 1980, Laclau abandonou sua perspectiva prévia e começou apregoar a emergência do pós-marxismo que tem no discurso o seu conceito central.

A posição que defendemos é que o conceito de ideologia na perspectiva althusseriana, longe de ter sido superado pelo de discurso, é mais preciso para o entendimento da realidade, seja para a análise da reprodução das relações de poder, seja para o diagnóstico das mudanças sociopolíticas. Ao contrário da concepção reducionista do discurso presente em Laclau, a perspectiva teórica althusseriana trata das diferentes práticas articuladas umas às outras, e a dominação de uma sobre as outras dependerá da contradição predominante em dada conjuntura. Isso significa que, embora haja a determinação em última instância pelo econômico, as diferentes estruturas que articulam o todo complexo possuem autonomia relativa e temporalidades distintas, não havendo margem para mecanicismos, nem reducionismos, nessa análise, já que há uma pluralidade de determinações, distintamente do "indeterminismo" relativista do pós-estruturalismo e do pós-marxismo. Ademais, negar o papel do econômico é no mínimo 
paradoxal pelo pós-estruturalismo e pelo pós-marxismo: como pensar o mundo hoje sem levarmos em conta os problemas de natureza econômica como o desemprego, inflação, taxas de juros, déficit fiscal, crise financeira do modelo neoliberal, dívida externa, ascensão dos BRICS e a crise econômica dos EUA e da Europa ocidental? O chamado "mundo vida" seria impermeável a essas situações? Cremos que não, e o marxismo althusseriano, nesse aspecto, sempre visou a análise e a articulação das diversas estruturas e práticas, e os diferentes níveis da cada estrutura em uma formação social, e na articulação desta com as demais formações socais com o objetivo de apontar as diferenças internas.

A despeito da mudança de paradigma de Laclau, isso não significa que sua contribuição inicial esteja obsoleta. Pelo contrário, sua contribuição ao conceito de ideologia é notável, e de grande valia para a análise de conjuntura. E, em tempos recentes, Laclau voltou a manifestar-se positivamente ao conceito de ideologia (Laclau 2002). E, como observa Liria (2002, p. 112) em relação a Althusser, faz-se o mesmo para Laclau: se aprendemos algo com Althusser é justamente reconhecer a autonomia de toda obra teórica a respeito de seu autor, e a combater as intrusões da subjetividade deste em seu próprio discurso teórico. Significa dizer que isso permite-nos ler em Laclau aquilo que há de mais crítico e criativo em sua contribuição teórica.

Luiz Eduardo Motta (luizpmotta@ig.com.br) é doutor em Sociologia pelo Instituto Universitário de Pesquisas do Rio de Janeiro (Iuperj) e professor de Ciência Política da Universidade Federal do Rio de Janeiro (UFRJ).

Carlos Henrique Aguiar Serra (chaserra@id.uff.br) é doutor em História pela Universidade Federal Fluminense (UFF) e professor de Ciência Política na mesma universidade.

\section{Referências}

Albuquerque, J.A.G. 1983. Althusser, a ideologia e as instituições. In L. Althusser. Aparelhos ideológicos de Estado. Rio de Janeiro: Graal.

Althusser, L.1976. Positions.Paris: Editions Sociales. 1977. Louis, La filosofia como arma de la revolución. México: Pasado y Presente. 1978. Posições 1. Rio de Janeiro: Graal.

1980. Ler o Capital. V. 2. Rio de Janeiro: J. Zahar Editores.

1986. Pour Marx.Paris: Editions La Découverte.

1988. Filosofia y marxismo. México: Siglo XXI.

1994. Écrits philosophiques et politiques. V. 1. Paris: Imec.

1997. Écrits philosophiques et politiques. V. 2. Paris: Imec.

1999. Sobre a reprodução. Petrópolis: Vozes.

2012. Sur la genèse. Décalages, 1(2), pp. 1-4.

s/d. A polemica sobre o humanismo. Lisboa: Presença.

Badiou, A.; Balmès, F. 1976. De l'ideologie. Paris: Maspero.

Barciela, G. 2011 Sobre parricídios y fidelidades: Ernesto Laclau y Alain Badiou, lectores de Althusser. In S. Caletti; R. Natalia, eds. La intervención de Althusser. Revisiones y debates. Buenos Aires: Prometeo.

Barret, M. 1996. Ideologia, política e hegemonia: de Gramsci a Laclau e Mouffe. In S. Zizek, ed. Um mapa da ideologia. Rio de Janeiro: Contraponto.

Bidet, J. 1999. À guisa de introdução: um convite a reler Althusser. In L. Althusser. Sobre a reprodução. Petrópolis: Vozes.

Boito Jr., A. 2007. Estado, política e classes. São Paulo:UNESP.

Boron, A. 2001. A coruja de Minerva. Petrópolis: Vozes.

Burdman, J. 2011. Distorción, transparencia y universalidade en la teoria de La ideologia. In S. Caletti; N. Romé; M. Sosa, eds. Lecturas de Althusser: proyecciones de un campo problemático. Buenos Aires: Imago Mundi.

Caletti, S.; Romé, N., eds. 2011. La intervención de Althusser. Revisiones y debates. Buenos Aires: Prometeo.

Caletti, S.; Romé, N.; Sosa, M., eds. 2011. Lecturas de Althusser: proyecciones de un campo problemático. Buenos Aires: Imago Mundi.

Cardoso, F.H. 1977. Estado capitalista e marxismo. Novos Estudos, 21, pp. 7-31. 
Eagleton, T. 1997. Ideologia. São Paulo: Boitempo.

Engels, F. 2010. As guerras camponesas na Alemanha. In A revolução antes da revolução. São Paulo: Expressão Popular.

Garo, I. 2008. La coupure impossible. L'idéologie en movement, entre philosophie et politique dans la pensée de Louis Althusser. In J-C. Bourdin, ed. Althusser: une lecture de Marx. Paris: PUF.

Gillot, P. 2010. Althusser y el psicoanálisis. Buenos Aires: Nueva Visión.

Escobar, C.H. 1975. Discursos, instituições e história. Rio de Janeiro: Editora Rio. 1978. Ciência da história e ideologia. Rio de Janeiro: Graal. 1996. Marx, filósofo da potência. Rio de Janeiro: Taurus.

Gramsci, A. 1980. Maquiavel, a política e o Estado moderno. Rio de Janeiro: Civilização Brasileira.

Hall, S. 1983. Da ideologia. Rio de Janeiro: Zahar Editores.

Konder, L. 2002. A questão da ideologia. São Paulo: Cia das Letras.

Ípola, E. 2007. Althusser, el infinito adiós. Buenos Aires: Siglo XXI.

Lacan, J. 1998. Escritos. Rio de Janeiro: J. Zahar Editores.

Laclau, E. 1979. Política e ideologia na teoria marxista. São Paulo: Paz e Terra 2002. Misticismo, retórica y política. Buenos Aires: Fondo de Cultura Econômica. 2008. Debates y combates. Buenos Aires: Fondo de Cultura Econômica. 2005. La razon populista. Buenos Aires: Fondo de Cultura Econômica.

2009. Populismo: que nos dice el nombre? in F. Panizza, ed. El populismo como espejo de la democracia. Buenos Aires: Fondo de Cultura Econômica. 2011. Emancipação e diferença. Rio de Janeiro: EDUERJ.

Laclau, E.; Mouffe, C. 2010. Hegemonia y estrategia socialista. Buenos Aires: Fondo de Cultura Econômica.

Lewis, W. 2005. The Under-Theorization of Overdetermination in Political Philosophy of Ernesto Laclau and Chantal Mouffe. Studies in Social and Political Thought, pp. 2-24. Disponível em: https:/www.sussex.ac.uk/webteam/gateway/file. php?name=11-1.pdf\&site=412. Acesso em: 8.jun.2014.

Liria, P.F. 2002. Regresso al 'campo de batalla'. In L. Althusser. Para un materialismo aleatório. Madrid: Arena Libros.

Marx, K. 2011. Grundrisse. São Paulo: Boitempo. 2012. Crítica do programa de Gotha. São Paulo: Boitempo.

Mendonça, D.; Rodrigues, L.P. 2008. Em torno de Ernesto Laclau. In D. Mendonça; L.P. Rodrigues, eds. Pós-estruturalismo e teoria do discurso: em torno de Ernesto Laclau. Porto Alegre: PUC-RS.

Motta, L.E. 2010. Poulantzas e o direito. Dados, 53(2), pp. 367-403.

Negri, A. 1993. Pour Althusser. Notes sur l'évolution de la pensée du dernier Althusser. In L. Althusser; D. Berger; B. Karsenti; T. Negri; N-E. Thevenin; J-M. Vincent. Sur Althusser passages. Paris: L'Harmattan.

Pêcheux, M. 2010. Semântica do discurso. Uma crítica à afirmação do óbvio. Campinas: Unicamp.

Pires, E. 1978a. Ideologia e Estado em Althusser: uma resposta. Encontros com a Civilização Brasileira, 6, pp. 11-40.

Poulantzas, N. 1974. Sobre el Estado Capitalista. Barcelona: Ed. Laia. 1978a. Fascismo e ditaduras. São Paulo: M. Fontes Editora. 1978b. L'Etat, le Pouvoir et le socialisme. Paris: PUF.

Rancière, J. 2011. La leçon d'Althusser. Paris: La Fabrique Éditions.

Saes, D. 2007. O impacto da teoria althusseriana da história na vida intelectual brasileira. In J.Q. Moraes, ed. História do Marxismo no Brasil. $2^{\mathrm{a}}$ ed. V. 3. Campinas: Unicamp.

Sales Jr., R. 2008. Laclau e Foucault: desconstrução e genealogia. In D. Mendonça; L.P. Rodrigues, eds. Pós-estruturalismo e teoria do discurso: em torno de Ernesto Laclau. Porto Alegre: PUC-RS.

Sampedro, F. 2010. A teoria da ideologia em Althusser. In M.B. Naves, ed. Presença de Althusser. Campinas: Unicamp.

Sosa, M.M. 2011. Discurso, política y sujeto: las huellas de la problemática althusseriana en la propuesta teórica de Ernesto Laclau. In S. Caletti; N. Romé, eds. La intervención de Althusser. Revisiones y debates. Buenos Aires: Prometeo.

Therborn, G. 1980. The Ideology of Power and the Power of Ideology. London: Verso.

Weffort, F. 1978. O populismo na política brasileira. Rio de Janeiro: Paz e Terra.

Zizek, S. 1996. O espectro da ideologia. In S. Zizek, ed. Um mapa da ideologia. Rio de Janeiro: Contraponto. 


\begin{abstract}
The political theory of Ernesto Laclau is a major reference in the field of political science to the debate on contemporary populism and democracy, as well as its contribution to the concept of ideology and discourse analysis. However, studies of this author have not explored the influence of Marxism, especially Louis Althusser in his work. The objective of this work is to rescue this influence and point the dialogue between these two authors, whose link concepts (which have some connection with Lacan's psychoanalysis) of ideology and overdetermination, beyond the issue of contingency that has become one of the most relevant to the work of both authors from the 1980s. To understand the contribution of Althusser and Laclau to analyze the concept of ideology on two axes: the first deals with the innovation that Althusser calls this concept to situate it in terms of imaginary relationships, and the definition of the decentered subject, then the contribution Laclau's from the assumptions Althusserians giving a new definition to the populistnationalist ideology, and the redefinition of his theory by privileging the concept of discourse to replace the ideology. In the conclusion we point out that the concept of ideology Althusser demonstrates more conceptual precision by be defined as a practice distinctly articulated with other practices of discursive conception (and reductionist) subsequently advocated by Laclau. We realize, therefore, that the theory of ideology Althusser remains current in the field of critical thinking, not only in regard to the reproduction aspects, but also the relations of power transformers.
\end{abstract}

KEYWORDS: Ideology; overdetermination; discourse; Althusser; Laclau. 